\title{
Psychosocial factors of deliberate self-harm in Afghanistan: a hospital based, matched case-control study
}

Akbar Paiman, ${ }^{1}$ Murad Khan, ${ }^{2}$ Tazeen Ali, ${ }^{3,4}$ Nargis Asad ${ }^{2}$ and Iqbal Azam ${ }^{4}$

${ }^{1}$ General Directorate of Preventive Medicine, Ministry of Public Health, Kabul, Afghanistan (Correspondence to Mohammad A. Paiman: Akbar. paiman@gmail.com). ${ }^{2}$ Department of Psychiatry; ${ }^{3}$ School of Nursing; ${ }^{4}$ Department of Community Health Sciences, Aga Khan University, Karachi, Pakistan.

\begin{abstract}
Background: Deliberate self-harm is not only a major global public health problem but also an important index of psychological distress and a risk factor for suicide.

Aims: We aimed to determine the psychosocial risk factors for deliberate self-harm in patients aged $\geq 16$ years presenting to tertiary care hospitals in Kabul, Afghanistan.

Methods: A matched case-control study was conducted from February 2015 to May 2015. We recruited 185 cases (patients with deliberate self-harm) and 555 age- and sex-matched controls (patients with general medical conditions) from 4 tertiary care hospitals in Kabul. We developed a questionnaire to record the sociodemographic characteristics of the participants, history of domestic violence, drug abuse and details about the act of deliberate self-harm, including the methods used. To assess depression and anxiety, we used the WHO self-reporting questionnaire (SRQ-20). Matched odds ratios with $95 \%$ confidence interval using conditional logistic regression were used to determine statistically significant associations between psychosocial factors and deliberate self-harm.
\end{abstract}

Results: Family conflicts, domestic violence, interpersonal arguments and living in extended families were found to be significantly associated with deliberate self-harm.

Conclusions: In Afghanistan, deliberate self-harm appears to be predominately related to interpersonal problems and family conflicts. About two-thirds of females and more than half of males scored positive for depression, yet none were receiving treatment for this. These findings have important policy implications for mental health and suicide prevention programmes in the country.

Keywords: psychosocial distress, deliberate self-harm, Afghanistan, mental health

Citation: Paiman A; Khan M; Ali T; Asad N; A Iqbal. Psychosocial factors of deliberate self-harm in Afghanistan: a hospital based, matched case-control study. East Mediterr Health J. 2019;25(11):798-805. https://doi.org/10.26719/emhj.19.021

Received: 07/07/17; accepted: 19/02/18

Copyright (c) World Health Organization (WHO) 2019. Some rights reserved. This work is available under the CC BY-NC-SA 3.o IGO license (https:// creativecommons.org/licenses/by-nc-sa/3.o/igo)

\section{Introduction}

Deliberate self-harm and self-injurious behaviours are major public health problems globally (1), particularly amongst young people (2). According to the World Health Organization (WHO) more than 800 ooo people commit suicide and 10-20 million people attempt deliberate selfharm worldwide every year (3). It is estimated the Asian continent contributes approximately $60 \%$ of global suicides (4).

Afghanistan is a low-income country with a population of approximately 34 million. Almost $46 \%$ of the population is under 15 years of age, and $74 \%$ of all Afghans live in rural areas and Islam is the predominant religion. The country has been in almost continuous war over the last 4 decades and has affected almost all aspects of peoples' lives, particularly their health, both mental and physical. Unemployment, poverty, depression, anxiety, domestic violence and exposure to trauma are the major contributors to compromised mental health $(5,6)$.

Suicide and deliberate self-harm are understudied subjects and there have been very few studies on these topics in Afghanistan. In a recent review of literature on suicidal behaviour in Afghanistan, only 7 published studies were identified (7); 6 of these were published between 2003 and 2016 and most of these focused on suicidal behaviour in women. A study on women $(n=172)$ in 3 drug use treatment centres in Afghanistan showed that $27 \%$ had attempted suicide in the month prior to admission to the centres (8). In 2014, the Ministry of Public Health published a report indicating that up to September 2014, 4466 cases of self-poisoning and 707 cases of self-immolation had been registered at various health facilities in Kabul, and 4136 cases of self-immolation and 166 confirmed suicides were reported from 30 other provinces of the country (9).

To the best of our knowledge, no study has been conducted previously on psychosocial factors associated with deliberate self-harm in Afghanistan.

\section{Methods}

\section{Study design}

This was a facility-based, sex- and age- ( \pm 5 years) matched 
case-control study of all patients aged 16 years and over presenting to tertiary care hospitals in Kabul, Afghanistan. The study was conducted to determine the association between psychosocial risk factors and deliberate self-harm. We matched for age and sex, as there is evidence to support the confounding effect of these 2 variables on deliberate self-harm (10).

\section{Instruments}

We developed a questionnaire to record the sociodemographic characteristics of the participants, history of domestic violence, drug use and details about the act of deliberate self-harm, including the methods used. To assess depression and anxiety, we used the WHO self-reporting questionnaire (SRQ-20) (11). The questionnaires were translated into 2 local languages, Pashto and Dari, and back-translated into English to measure for consistency. It was pre-tested in 3 tertiary care hospitals in Kabul. The content validity index was established for clarity and relevancy, with scores of $87 \%$ and $83 \%$ respectively (mean $85 \%$ ) for Dari and $80 \%$ and $82 \%$ respectively (mean $81 \%$ ) for Pashto.

The self-reporting questionnaire has 20 questions with each positive response having a score of 1 and each negative response having a score of 0 , making a maximum total score of 20 . A score of $\geq 9$ for this tool is considered positive for depression and anxiety. Domestic violence included verbal and physical abuse. "Fight in the family" was defined as verbal arguments or physical fights between family members, in which the participant may or may not have been involved. "Fighting with someone" was defined as physical fight inside or outside the family involving the participant.

A face-to-face interview method was used for data collection. For each case, 3 age- and sex-matched controls were selected.

\section{Ethical considerations}

Ethical approval was obtained from the ethics review committee of the Aga Khan University, Karachi, Pakistan, and the institutional review board of the Ministry of Public Health in Kabul. Written informed consent was obtained from the participants (IRB No: 479966).

The study was carried out in partial requirement (thesis) for completion of the MSc programme in epidemiology and biostatistics (Study No: 3231-CHS ERC-14) of the first author.

\section{Sample size}

We used NCSS PASS software, trial version 13, for sample size calculation. Using prevalence of psychosocial factors among controls as $20 \%$ to $75 \%$, anticipated matched odds ratio of $\geq 2$, correlation between cases and controls of 0.2 and level of significance as $5 \%$, a sample size of 160 cases and 480 matched controls was calculated. We used a purposive sampling technique, i.e., selection of patients who fulfil eligibility criteria.

Cases were patients who presented with an act of deliberate self-harm diagnosed by physicians. Controls were patients admitted for other medical conditions and did not have a prior history of deliberate self-harm. Only those who agreed to be interviewed and gave written informed consent (adults) or assent (adolescents) were included in the study. Due to the limited time available for the study, 4 hospitals in Kabul that had high turnover of patients were selected as the study sites. For each case, 3 controls were selected.

The researcher met with the management of the selected health facilities and explained the study protocol, including the selection criteria for cases and controls. The deliberate self-harm case was first identified by the treating physician. Controls were selected from a daily list of non-deliberate self-harm patients in each of the study sites, and for each case 3 sex- and age-matched controls were randomly selected. Exclusion criteria for the cases included patients with mental retardation, those with cognitive impairment or those on mechanical ventilators who could not be interviewed. Among cases, 2 female patients who were in a critical condition as a result of deliberate self-harm (and later died) were excluded. Similarly, among the controls 4 patients were excluded due to their seriously compromised medical condition. The interviews were conducted in 4 tertiary care hospitals (Ibn-e-Sina, Jamhoriate, Istiqlal and Rabia Balkhy) at the bedside of patients. The interviews were conducted by the principle investigator. All the interviews were conducted by a male researcher (principle investigator) as we did not have funds to pay data collectors. The interview took around 45 minutes for each patient.

\section{Statistical analysis}

Data were entered twice in EpiData and imported into STATA, version 12, for analysis. Cross-tabulation between case-control status and socioeconomic, demographic and psychological factors were done to observe the distribution of these variables. The associations of these factors were observed both at univariate and multivariable levels, using crude and adjusted matched odds ratio (MOR) with 95\% confidence interval.

A factor was considered eligible for multivariable analysis if its $P$-value was less $<0.25$ at univariate level.

Conditional logistic regression via a stepwise selection method was used to obtain the final model. A P-value < 0.05 was considered statistically significant. Two-way plausible interactions were checked between domestic violence and anxiety and depression, family conflict and ethnicity, family type and family conflict, and finally the interaction between ethnicity and anxiety and depression.

\section{Results}

A total of 185 cases and 555 matched controls were included in the study. The median age of the participants was 20 (interquartile range 18-24; range 16-58) years. Females made up $85 \%$ of participants, and $60 \%$ of these were housewives. Around $45 \%$ of the participants had a monthly family income < 10000 afghanis (US\$ 147). About two-thirds of the cases and just over $40 \%$ of the 


\begin{tabular}{|c|c|c|c|c|c|c|}
\hline \multirow[t]{2}{*}{ Factor } & \multicolumn{2}{|c|}{$\begin{array}{c}\text { Cases } \\
(n=185)\end{array}$} & \multicolumn{2}{|c|}{$\begin{array}{l}\text { Controls } \\
(n=555)\end{array}$} & \multirow[t]{2}{*}{$\begin{array}{l}\text { Crude MOR } \\
\quad(95 \% \mathrm{CI})\end{array}$} & \multirow[t]{2}{*}{ P-value } \\
\hline & No. & $\%$ & No. & $\%$ & & \\
\hline Ethnicity & & & & & & $<0.001$ \\
\hline Pashtun & 29 & 15.7 & 210 & 37.8 & 1.0 & \\
\hline Tajik & 123 & 66.5 & 232 & 41.8 & $3.8(2.4-5.9)$ & \\
\hline Hazara & 28 & 15.1 & 74 & 13.3 & $2.6(1.5-4.7)$ & \\
\hline Other & 5 & 2.7 & 39 & 7.0 & $0.9(0.3-2.4)$ & \\
\hline Sect & & & & & & 0.70 \\
\hline Sunni & 157 & 84.9 & 478 & 86.1 & 1.0 & \\
\hline Shia & 28 & 15.1 & 77 & 13.9 & $1.1(0.6-1.5)$ & \\
\hline Marital status & & & & & & 0.20 \\
\hline Single & 90 & 48.6 & 278 & 50.1 & 1.00 & \\
\hline Engaged & 32 & 17.3 & 69 & 12.4 & $1.40(0.5-1.5)$ & \\
\hline Married & 63 & 34.1 & 208 & 37.5 & $0.86(0.7-1.7)$ & \\
\hline Type of family & & & & & & $<0.001$ \\
\hline Nuclear & 74 & 40.0 & 372 & 67.0 & 1.0 & \\
\hline Extended & 111 & 60.0 & 183 & 33.0 & $3.2(2.2-4.6)$ & \\
\hline Education level (years) & & & & & & 0.01 \\
\hline No schooling & 57 & 30.8 & 212 & 38.2 & 1.0 & \\
\hline $1-5$ & 13 & 7.0 & 50 & 9.0 & $0.8(0.4-1.9)$ & \\
\hline $6-12$ & 101 & 55.0 & 243 & 44.0 & $1.8(1.1-2.4)$ & \\
\hline $13-18$ & 14 & 7.0 & 50 & 9.0 & $1.1(0.5-2.1)$ & \\
\hline Family income (afghanis) ${ }^{a}$ & & & & & & 0.01 \\
\hline$<10000$ & 92 & 49.7 & 242 & 43.8 & 1.0 & \\
\hline $10000-19999$ & 43 & 23.2 & 196 & 35.3 & $0.6(0.4-0.9)$ & \\
\hline $20000-29999$ & 50 & 27.0 & 117 & 21.1 & $1.1(0.7-1.7)$ & \\
\hline$\geq 30000$ & 5.0 & 2.7 & 3 & 0.5 & $1.6(0.4-6.6)$ & \\
\hline Death of family member in past year & & & & & & $<0.001$ \\
\hline No & 16 & 8.6 & 536 & 96.6 & 1.0 & \\
\hline Yes & 24 & 13.0 & 19 & 3.4 & $3.9(19.2-144.0)$ & \\
\hline Broken relationship in past year & & & & & & $<0.001$ \\
\hline No & 163 & 88.1 & 548 & 98.7 & 1.0 & \\
\hline Yes & 20 & 10.8 & 6 & 1.1 & $11.6(4.4-31.0)$ & \\
\hline Loss in business & & & & & & 0.003 \\
\hline No & 156 & 84.3 & 512 & 92.3 & 1.0 & \\
\hline Yes & 29 & 15.7 & 43 & 7.7 & $2.2(1.3-3.7)$ & \\
\hline Interpersonal relationship problem in past year & & & & & & $<0.001$ \\
\hline No & 73 & 39.5 & 501 & 90.3 & 1.0 & \\
\hline Yes & 112 & 60.5 & 54 & 9.7 & $17.9(1.0-30.0)$ & \\
\hline Forced displacement from home in past year & & & & & & $<0.001$ \\
\hline No & 161 & 87.0 & 545 & 98.2 & 1.0 & \\
\hline Yes & 24 & 13.0 & 10 & 1.8 & $7.2(3.0-15.0)$ & \\
\hline Conflict/argument in family & & & & & & $<0.001$ \\
\hline No & 46 & 24.9 & 461 & 83.1 & 1.0 & \\
\hline Yes & 139 & 75.1 & 94 & 16.9 & $15.2(9.0-25.0)$ & \\
\hline
\end{tabular}




\begin{tabular}{|c|c|c|c|c|c|c|}
\hline \multirow[t]{2}{*}{ Factor } & \multicolumn{2}{|c|}{$\begin{array}{c}\text { Cases } \\
(n=185)\end{array}$} & \multicolumn{2}{|c|}{$\begin{array}{l}\text { Controls } \\
(n=555)\end{array}$} & \multirow[t]{2}{*}{$\begin{array}{c}\text { Crude MOR } \\
(95 \% \text { CI })\end{array}$} & \multirow[t]{2}{*}{$P$-value } \\
\hline & No. & $\%$ & No. & $\%$ & & \\
\hline Exposure to domestic violence & & & & & & $<0.001$ \\
\hline No & 50 & 26.5 & 473 & 85.2 & 1.0 & \\
\hline Yes & 135 & 73.0 & 82 & 14.8 & $24.6(13.7-45.3)$ & \\
\hline Being tortured & & & & & & $<0.001$ \\
\hline No & 169 & 91.4 & 554 & 99.8 & 1.0 & \\
\hline Yes & 16 & 8.6 & 1 & 0.2 & $48.0(6.5-360.0)$ & \\
\hline Anxiety and depression & & & & & & $<0.001$ \\
\hline No & 45 & 24.3 & 467 & 84.1 & 1.0 & \\
\hline Yes & 140 & 75.7 & 88 & 15.9 & $18.7(11.1-31.0)$ & \\
\hline Yes & 139 & 75.1 & 94 & 16.9 & $15.2(9.0-25.0)$ & \\
\hline
\end{tabular}

MOR = matched odds ratios. $C I=$ confidence interval. ${ }^{a} U S \$ 1=68$ afghanis.

controls belonged to the Tajik ethnic group (Table 1).

Death of a family member, loss of business, interpersonal relationship problems and forceful displacement from home in the past year were more common in cases than controls. Similarly, the incidence of conflict/argument in the family, exposure to domestic violence and torture were reported more frequently in cases.

Over two-thirds $(73 \%)$ of the females and more than half $(57 \%)$ of the males scored positive for depression and anxiety on the self-reporting questionnaire.

The most common methods of deliberate selfharm were medication overdose (118, 64\%) and organophosphate/rodent killer ingestion (61, 33\%). Other methods included self-cutting, shooting and attempted hanging (6,3\%). A 2-way interaction between depression and anxiety and ethnicity was observed as statistically significant $(P<0.05)$ among biologically plausible interactions (Table 2).

There was a statistically significant association between ethnicity and deliberate self-harm $(P<0.001)$, with Tajiks or Hazara at higher risk compared to Pashtuns.

Other statistically significant associations are listed in Table 1. Of these, some (being tortured or displaced from home) appear to be directly related to the on-going conflict in Afghanistan, while others (family conflicts, domestic violence, etc.) are found in many other settings around the world.

None of the cases in our study were receiving treatment for their mental health problems. This information was not part of the questionnaire but the investigator witnessed that none of the deliberate selfharm patients were referred to a mental health specialist or psychosocial support unit; they were only receiving treatment for their physical condition, e.g., stomach lavage for medication overdose patients and rodent killer ingestion, etc. All of them were discharged from hospital to their homes after receiving treatment.
In multivariable analysis, family conflicts $(\mathrm{MOR}=$ 6.2; 95\% CI: 2.56-15.24), domestic violence (MOR = 6.4; 95\% CI: 2.71-17.30), interpersonal arguments (MOR = 3.0; 95\% CI: 1.22-7.52), living in extended families (MOR = 2.5; 95\% CI: 1.34-5.22) and being tortured (MOR=2.5; 95\% CI:1.2-5.2) were found to be statistically significantly associated with DSH (Table 2).

\section{Discussion}

The male:female ratio in our study was 1:5 with 157/185 $(85 \%)$ of the cases being women and $60 \%$ of these were housewives. Since deliberate selfharm is a proxy indicator of psychological distress, our finding on male/female differences highlights the status of women in Afghan society and the kind of psychological stress they are living under. The fact that the majority of women were housewives also highlights the difficulties many married women in Afghanistan face, including domestic violence and abuse $(8,12,13)$. It is also possible there may be systematic underreporting of suicide and deliberate self-harm in men in Afghanistan, as highlighted in a recent (2014) study (14).

About two-thirds (73\%) of females and more than half (57\%) of the males scored positive for depression and anxiety. Despite this, none were receiving treatment for their mental health problems, underscoring the unmet need for recognition and treatment of common mental disorders in Afghanistan.

Our findings showed a significant association between interpersonal and family conflicts and deliberate self-harm. Several previous studies also indicate that family conflicts are associated with deliberate selfharm (15-17). Family conflicts lead to anger, depression, anxiety and low self-esteem and contribute to the increasing burden of deliberate self-harm $(1,15,18)$. Some of the underlying factors in Afghanistan include strict cultural rules, where an individual must stay with his/ her spouse or parents despite conflicts between them. 


\begin{tabular}{|c|c|}
\hline Factor $^{\mathrm{a}}$ & $\begin{array}{l}\text { Adjusted MOR } \\
(95 \% \mathrm{CI})\end{array}$ \\
\hline \multicolumn{2}{|c|}{ Family conflicts } \\
\hline No & 1.0 \\
\hline Yes & $5.9(2.5-13.9)^{*}$ \\
\hline \multicolumn{2}{|c|}{ Domestic violence } \\
\hline No & 1.00 \\
\hline Yes & $5.7(2.4-13.5)^{*}$ \\
\hline \multicolumn{2}{|c|}{ Interpersonal relationship problems with others } \\
\hline No & 1.0 \\
\hline Yes & $3.1(1.3-7.5)^{*}$ \\
\hline \multicolumn{2}{|l|}{ Family type } \\
\hline Nuclear & 1.0 \\
\hline Extended & $2.5(1.2-5.2)^{*}$ \\
\hline \multicolumn{2}{|c|}{ Being tortured } \\
\hline No & 1.0 \\
\hline Yes & $17.8(1.3-248.8)^{*}$ \\
\hline \multicolumn{2}{|c|}{ Ethnicity: anxious and depressed } \\
\hline Pashtun & 1.0 \\
\hline Tajik & $6.8(1.8-28.8)^{*}$ \\
\hline Hazara & $9.2(1.5-60.3)^{*}$ \\
\hline Other & $2.5(0.1-42.5)$ \\
\hline \multicolumn{2}{|c|}{ Ethnicity: not anxious and depressed } \\
\hline Pashtun & 1.0 \\
\hline Tajik & $1.9(0.7-5.2)$ \\
\hline Hazara & $0.1(0.02-0.9)$ \\
\hline Other & $0.5(0.04-4.7)$ \\
\hline
\end{tabular}

MOR = matched odds ratios. $C I=$ confidence interval.

${ }^{a}$ Factors with $\mathrm{P}<0.25$ at univariate level were analysed at multivariate level. ${ }^{*}$ Statistically significant $(P<0.05)$.

Divorce and separation are highly stigmatized in Afghan society. Openly criticizing one's in-laws by the woman is frowned upon. Thus, victims of family and interpersonal conflicts have very little social support and continue to suffer emotionally (19).

The same applies to conflicts between parents and their children, especially daughters. Leaving the parental home due to conflict with parents is unacceptable in Afghan culture and stigmatizes the whole family socially. For example, if a girl "escapes" from her home, there are repercussions for her sisters. Also, the war has had a severe impact on traditional family support in Afghanistan and the apparent increase in family conflicts may be a direct consequence of this (20).

Almost three-quarters of our cases experienced domestic violence. Research from other settings also shows that domestic violence is a well-documented risk factor for deliberate self-harm. Women have a subordinate status in the highly patriarchal and conservative Afghan society $(15,21,22)$.

We also found that living in extended families was a risk factor for deliberate self-harm. While this type of living situation is quite common in Afghanistan, it is also a source of conflict between the older and younger generations. The elders of the family (parents and grandparents) usually make major decisions about sons, daughters and even grandchildren. Most marriages in Afghanistan are arranged and parents or grandparents usually make the choice of marital partner. There are many cases where the marital relationship is not successful but there are very few avenues for separation (particularly for females), which leads to increased psychological distress, increasing the risk of deliberate self-harm. Our findings are in line with research on intergenerational conflicts in other parts of the world $(23,24)$.

The reported association between undergoing torture and deliberate self-harm is also well documented (25).

Our study reported a significant 2-way interaction between ethnicity and depression and anxiety with deliberate self-harm, i.e., ethnicity, depression and anxiety interact together and contribute to deliberate self-harm differently in varied ethnic groups. We found that among our participants, anxious and depressed Tajik and Hazara are at higher risk of deliberate self-harm than Pashtuns. Previous research has also reported interaction between, sex, education and ethnicity $(25,26)$.

The most common method of deliberate self-harm in our study was ingestion of substances. Almost twothirds of cases used medications while one-third used a rodent killer. Both methods can cause serious medical complications, in particular, the toxicity of the latter leads to a high case-fatality index. There is a need to control the easy availability of both medications and toxic substances.

There were several strengths to our study. These included a matched case-control design and a larger sample size than required, with a case:control ratio of 1:3. We also used a structured questionnaire to obtain information and calculated the content validity index for the study tool.

There were some limitations to our study. We did not exclude medically serious deliberate self-harm participants (seriously ill patients who were in severe pain might have exaggerated in answering the questions). Including only domestic violence and the exclusion of other types of violence, and the fact that we relied on the admitting physician for identification of cases of deliberate self-harm, may have led to selection bias or some cases being undetected due to sociocultural factors. In addition, the study was carried out in only 4 hospitals in Kabul, therefore our findings may not be generalized to the rest of the country.

\section{Recommendations}

Since deliberate self-harm is a proxy indicator of psychological distress, to address high levels of psychological distress in the population, there is need to develop evidence-based programmes for primary and secondary prevention of deliberate self-harm. As a first step, the setting up of surveillance systems would be required to monitor all cases of deliberate self-harm presenting to 
all health facilities in the country. The data could be analysed for trends and patterns over time.

There is an urgent need for a national centre for the management of poisoning in Afghanistan: 97\% of our cases reported medication over-dose and ingestion of poison, the most common being rodent killer. Most of the cases $(64 \%)$ took an overdose of medication and most of these took more than one medication. There is need to control the over-the-counter availability of medications as well training of physicians in rational drug prescribing in Afghanistan.
There is also a need for public awareness programmes regarding mental health and suicidal behaviour in Afghanistan. Both electronic and print media should be utilized, and religious scholars and public and mental health professionals should work collaboratively for this.

Lastly, there is need for further research on suicidal behaviour and mental health in Afghanistan.

Funding: None.

Competing interests: None declared.

\section{Facteurs psychosociaux du comportement auto-agressif, en Afghanistan : étude avec cas et témoins appariés en milieu hospitalier}

\section{Résumé}

Contexte : Le comportement auto-agressif est non seulement un problème de santé publique mondial majeur, mais aussi un signe manifeste de détresse psychosociale et un facteur de risque de suicide.

Objectif : L'objectif de la présente étude était de déterminer les facteurs de risques psychosociaux du comportement auto-agressif chez des patients âgés de 16 ans et plus en consultation au sein de centres hospitaliers de soins tertiaires à Kaboul (Afghanistan).

Méthodes: Une étude avec cas et témoins appariés a été menée de février à mai 2015. Nous avons recruté 185 cas (patients atteints de comportement auto-agressif) et 555 témoins appariés selon l'âge et le sexe (patients atteints d'autres affections générales) consultant dans quatre centres hospitaliers de soins tertiaires à Kaboul. Nous avons mis au point un questionnaire pour enregistrer les caractéristiques sociodémographiques des participants, les antécédents de violence domestique, la toxicomanie et des détails sur le comportement auto-agressif, y compris les méthodes utilisées. Pour évaluer la dépression et l'anxiété, nous avons utilisé le questionnaire d'auto-évaluation de l'OMS (SRQ-20). Des odds ratios appariés assortis d'intervalles de confiance à $95 \%$ obtenus par la régression logistique conditionnelle ont été utilisés afin de déterminer des associations statistiquement significatives entre les facteurs psychosociaux et le comportement auto-agressif.

Résultats : Les conflits familiaux, la violence domestique, les différends interpersonnels et la vie au sein de familles élargies se sont révélés être associés de manière significative au comportement auto-agressif.

Conclusions : En Afghanistan, le comportement auto-agressif semble être principalement lié à des problèmes interpersonnels, ainsi qu'à des conflits familiaux. Près de deux tiers des femmes et plus de la moitié des hommes avaient un score positif pour la dépression; pourtant, aucun n'était en traitement pour cette affection. Ces résultats ont des incidences politiques importantes sur les programmes de santé mentale et de prévention du suicide au sein du pays.

$$
\begin{aligned}
& \text { العو امل النفسية الاجتهاعية لإيذاء الذات المتعمد في كابول بأفغانستان: دراسة للحالات و الشو اهد المتو افقة في } \\
& \text { المستشفيات } \\
& \text { أكبر بيمان، مراد خان، تازين علي، نرجس أسد، إقبال عزام } \\
& \text { الخالاصة } \\
& \text { الخلفية: تعمُّد إيذاء الذات ليس مشكلة كبرى من مشكلات الصحة العامة العالمية فحسب، بل هو أيضاً مؤشر مهم للضائقة النفسية وعامل من الصن } \\
& \text { عوامل الخطر التي تُفضي إلى الانتحار. }
\end{aligned}
$$

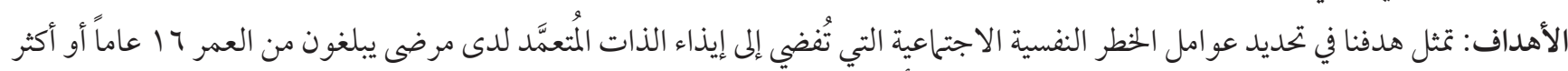

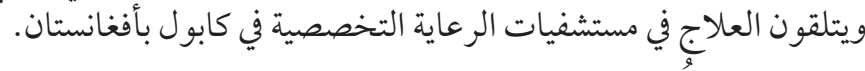

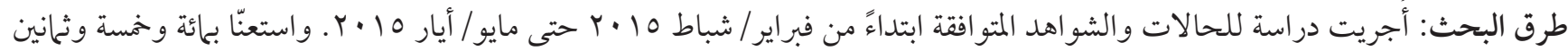

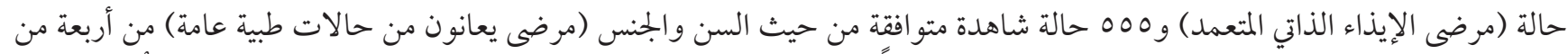

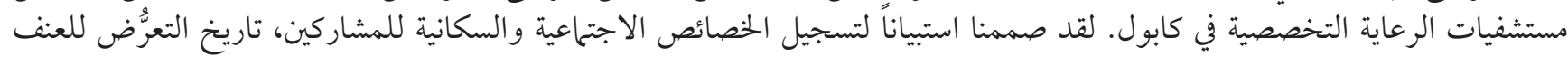

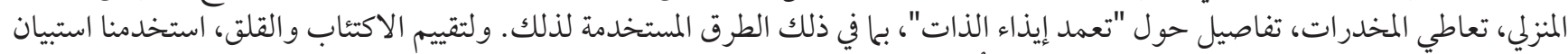

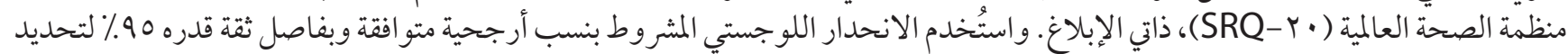

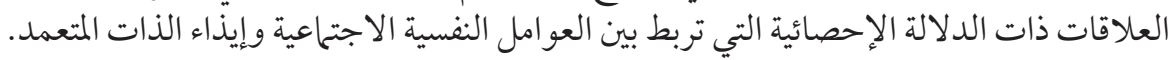




$$
\begin{aligned}
& \text { مفككة. النتائج: تبيَّن أن تعمُّد إيذاء الذات يرتبط ارتباطاً وثيقاً بالخلافات الأسرية، والعنف المنزلي، والسجالات المتبادلة بين الأشخاص، والعيش في أسر }
\end{aligned}
$$

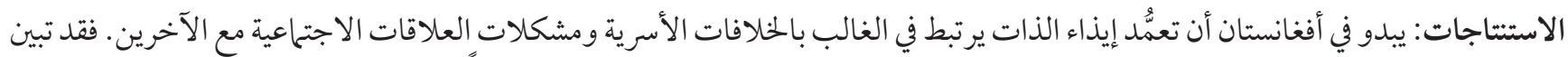

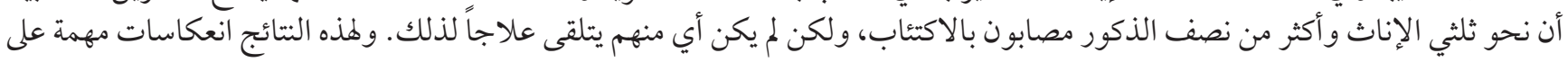

$$
\begin{aligned}
& \text { سياسات برامج الصحة النفسية والوقاية من الانتحار في البلد. }
\end{aligned}
$$

\section{References}

1. Hawton K, James A. Suicide and deliberate self harm in young people. BMJ. 2005;330(7496):891. DOI:10.1136/bmj.330.7496.891

2. Cooper J, Kapur N, Webb R, Lawlor M, Guthrie E, Mackway-Jones K, et al. Suicide after deliberate self-harm: a 4-year cohort study. Am J Psychiatry. 2005;162(2):297-303. doi:10.1176/appi.ajp.162.2.297

3. Preventing suicide: a global imperative. Geneva: World Health Organization; 2104:92 (https://www.who.int/mental_health/suicide-prevention/world_report_2014/en/, accessed 3 April 2019).

4. Chen Y-Y, Wu KC-C, Yousuf S, Yip PS. Suicide in Asia: opportunities and challenges. Epidemiol Rev. 2011:mxro25. PMID:22158651

5. Miller KE, Omidian P, Rasmussen A, Yaqubi A, Daudzai H. Daily stressors, war experiences, and mental health in Afghanistan. Transcult Psychiatry. 2008;45(4):611-38. PMID:19091728

6. Kleiman EM, Liu RT. Social support as a protective factor in suicide: findings from two nationally representative samples. J Affect Disord. 2013;150(2):540-5. PMID:23466401

7. Paiman M, Khan M. Suicide and deliberate self-harm in Afghanistan. Asian J Psychiatr. 2017 Apr;26:29-31. doi:10.1016/j. ajp.2017.01.004.

8. Abadi MH, Shamblen SR, Johnson K, Thompson K, Young L, Courser M, et al. Examining human rights and mental health among women in drug abuse treatment centers in Afghanistan. Int J Womens Health. 2012;4:155-65. doi:10.2147/IJWH.S28737

9. Press report. Ministry of Public Health, Ministry of Women's Affairs and UN call for efforts to strengthen suicide prevention in Afghanistan. Kabul: Ministry of Public Health; 2014.

10. Milner A, Krnjacki L, LaMontagne A. Age and gender differences in the influence of social support on mental health: a longitudinal fixed-effects analysis using 13 annual waves of the HILDA cohort. Public Health. 2016;140:172-8. doi:10.1016/j. puhe.2016.06.029

11. Ventevogel P, De Vries G, Scholte WF, Shinwari NR, Faiz H, Nassery R, et al. Properties of the Hopkins Symptom Checklist-25 (HSCL-25) and the Self-Reporting Questionnaire (SRQ-20) as screening instruments used in primary care in Afghanistan. Soc Psychiatry Psychiatr Epidemiol. 2007 Apr;42(4):328-35.

12. Padovese V, De Martino R, Eshan MA, Racalbuto V, Oryakhail MA. Epidemiology and outcome of burns in Esteqlal Hospital of Kabul, Afghanistan. Burns. 2010;36:1101-6. doi:10.1016/j.burns.2010.01.003

13. Gladstone GL, Parker GB, Mitchell PB, Malhi GS, Wilhelm K, Austin M-P. Implications of childhood trauma for depressed women: an analysis of pathways from childhood sexual abuse to deliberate self-harm and revictimization. American Journal of Psychiatry. 2004;161(8):1417-25. PMID:17370049

14. Loredo J, Manalai P. Suicide in men is systematically underreported in Afghanistan. J Medicine in the Tropics. 2014;16(2):109.

15. Asgeirsdottir BB, Sigfusdottir ID, Gudjonsson GH, Sigurdsson JF. Associations between sexual abuse and family conflict/ violence, self-injurious behavior, and substance use: the mediating role of depressed mood and anger. Child Abuse Negl. 2011 Mar;35(3):210-9. doi:10.1016/j.chiabu.2010.12.003.

16. Greydanus DE, Shek D. Deliberate self-harm and suicide in adolescents. Keio J Med. 2009 Sep;58(3):144-51. PMID:19826208

17. Ahmadi A, Mohammadi R, Almasi A, Amini-Saman J, Sadeghi-Bazargani H, Bazargan-Hejazi S, et al. A case-control study of psychosocial risk and protective factors of self-immolation in Iran. Burns. 2015 Mar;41(2):386-93. doi:10.1016/j.burns.2014.07.025

18. Ahmadi A, Mohammadi R, Schwebel DC, Yeganeh N, Soroush A, Bazargan-Hejazi S. Familial risk factors for self-immolation: a case-control study. J Womens Health (Larchmt). 2009 Jul;18(7):1025-31. doi:10.1089/jwh.2008.1192

19. Scholte WF, Olff M, Ventevogel P, de Vries G-J, Jansveld E, Cardozo BL, et al. Mental health symptoms following war and repression in eastern Afghanistan. JAMA. 2004;292(5):585-93. doi:10.1001/jama.292.5.585

20. Lizardi D, Grunebaum M, Burke A, Stanley B, Mann J, Harkavy-Friedman J, et al. The effect of social adjustment and attachment style on suicidal behaviour. Acta Psychiatr Scand. 2011 Oct;124(4):295-300. doi:10.1111/j.1600-0447.2011.01724.X

21. Billaud J. Suicidal performances: voicing discontent in a girls' dormitory in Kabul. Cult Med Psychiatry. 2012 Jun;36(2):264-85. doi:10.1007/s11013-012-9262-2

22. Chowdhury AN, Brahma A, Banerjee S, Biswas M. Pattern of domestic violence amongst non-fatal deliberate self-harm attempters: a study from primary care of West Bengal. Indian J Psychiatry. 2009 Apr;51(2):96-100. doi:10.4103/0019-5545.49448

23. Kumar PS, Rajmohan V, Sushil K. An exploratory analysis of personality factors contributed to suicide attempts. Indian J Psychol Med. 2013 Oct;35(4):378-84. doi:10.4103/0253-7176.122231 
24. Singh V, Gupta DK, Desai NG, Srivastava A, Chaudhry R, Varma A, et al. Sociodemographic and clinical profile of patients with attempted suicide attending emergency services at the mental health institute in Northern India. J Mental Health Hum Behav. 2014;19(2):69.

25. Riolo SA, Nguyen TA, Greden JF, King CA. Prevalence of depression by race/ethnicity: findings from the National Health and Nutrition Examination Survey III. Am J Public Health. 2005;95(6):998-1000. PMID:15914823

26. Wiebke Lamer Erin Foster. Afghan ethnic groups: a brief investigation. Norfolk, Virginia: Civil-Military Fusion Centre; 2011 (https://reliefweb.int/report/afghanistan/afghan-ethnic-groups-brief-investigation, accessed 16 April 2019). 